\title{
New constraints on the origin of carbonates in kimberlites integrating petrography, mineral chemistry and in situ stable isotope analysis
}

\author{
Montgarri Castillo-Oliver ${ }^{1}$, Andrea Giuliani ${ }^{1,2}$, William L. Griffin ${ }^{1}$, Suzanne Y. \\ $O^{\prime}$ Reilly $^{1}$, Emilie Thomassot ${ }^{3}$ and Russell N. Drysdale ${ }^{4}$ \\ ${ }^{1}$ ARC Centre of Excellence for Core to Crust Fluid Systems and GEMOC, Department of Earth and Planetary \\ Sciences, Macquarie University, NSW, Australia \\ ${ }^{2}$ School of Earth Sciences, The University of Melbourne, Parkville, 3010 Victoria, Australids[ip: \\ ${ }^{3}$ Centre de Recherches Pétrographiques et Géochimiques, CNRS, Nancy, France \\ ${ }^{4}$ School of Geography, The University of Melbourne, Parkville, 3010 Victoria, Australia
}

\section{Introduction}

The composition of kimberlite parental melts and their evolution remains a controversial topic because of the heterogeneous nature of kimberlites and volatile loss or addition during and after eruption. The original composition of these magmas can be significantly modified by a wide variety of processes that take place during, or subsequent to, kimberlite emplacement. These processes may include mantle and crustal assimilation, degassing, deuteric and hydrothermal alteration and/or weathering. Carbonates in kimberlites are the main site for $\mathrm{CO}_{2}$, and include calcite and dolomite, and very rare alkali-rich carbonates (e.g., Mitchell 1994; Kamenetsky et al. 2007). Despite being major components in hypabyssal kimberlites (Skinner and Clement,1979), very few studies have included quantitative majorand minor-element analyses of kimberlitic carbonates and detailed petrographic observations. However, the few studies already suggest that carbonate petrogenesis in kimberlites is very complex and involves multiple sources in their formation (e.g., Armstrong et al. 2004; Giuliani et al. 2014). Understanding the origin of carbonates in kimberlites is thus essential to determine the $\mathrm{CO}_{2}$ compostion of parental melts. In this study carbonates in fresh hypabyssal kimberlites (macrocrystic and aphanitic types) from worldwide localities (South Africa, Canada, Finland, Australia, Antarctica, Brazil) are characterised by detailed petrography, as well as by major- and minor-element, bulk-carbonate and in situ secondary ion mass spectrometry (SIMS) O-isotope analyses.

\section{Carbonate petrogenesis in kimberlites}

Detailed petrographic characterisation of these kimberlites was carried out using optical microscopy, cold cathodoluminiscence and SEM. This detailed examination emphasises the complexity of kimberlites and identifies multiple generations of carbonates within each sample.

Groundmass carbonates in most samples occur as fine-grained interstitial calcite between other nonaltered groundmass crystals such as olivine, monticellite, apatite and/or perovskite. However, some kimberlites (e.g., De Beers kimberlite), also contain randomly oriented laths $(80 x 1500 \mu \mathrm{m})$ of calcite, with inclusions of the same groundmass minerals. Similar laths have been previously interpreted as being of primary (i.e. magmatic) origin (e.g., Kopylova et al. 2007). Likewise, the euhedral Ba-, Na-, $\mathrm{Ce}$ - and $\mathrm{Nb}$-rich carbonates, found here either as individual grains or as part of complex segregations (in the Koala kimberlite), may be comparable to the high-temperture, primary carbonates described in other kimberlites of the Lac de Gras field (Armstrong et al., 2004). The work presented here also includes other well-known examples of primary carbonate, such as the Benfontein carbonate sills and diapirs (e.g., Dawson and Hawthorne, 1973). Most of these primary carbonates have a moderate cathodoluminescence response, resulting in brown to dark orange CL colours (fig.1). However, there are also remarkable exceptions, such as the segregations in the Koala kimberlite and the diapirs in the Benfontein kimberlite, which have a strong CL response.

Secondary (non-magmatic) carbonates may also occur in the studied kimberlites either replacing the original groundmass phases, as segregations or as crosscutting veins. Some of the secondary carbonates 
(calcite and, less commonly, dolomite) are characterised by abundant inclusions, such as barite, apatite, halides or fluorite. These secondary carbonates are typically characterised either by bright yellow and orange CL colours or, less commonly, by no CL response.
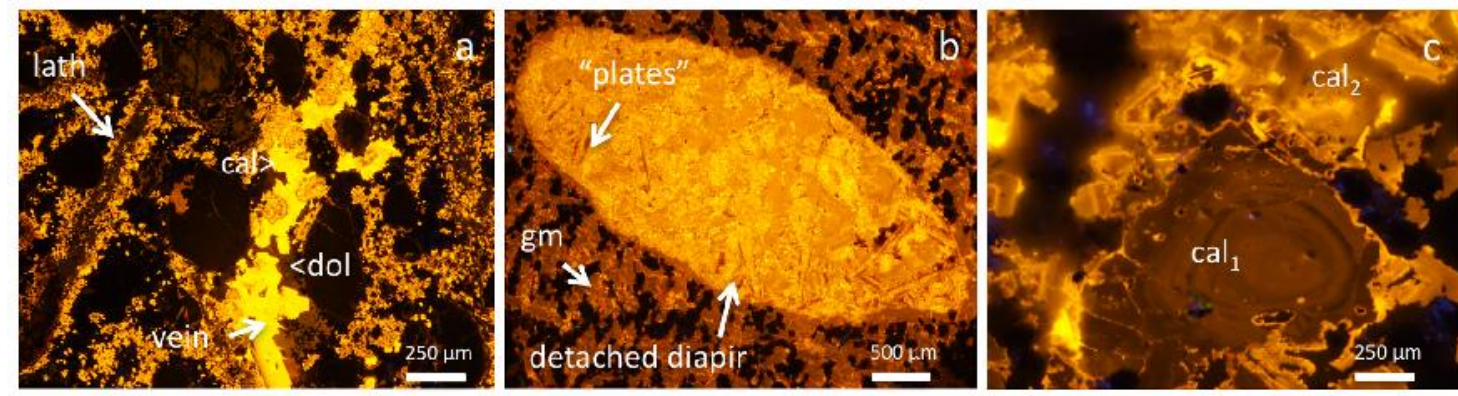

Figure 1: Cold CL images of selected kimberlites. a) De Beers kimberlite, with primary carbonate laths (brown) and secondary veins of calcite (bright yellow) and dolomite (dark red). b) A "detached diapir" of the lower sill at Benfontein; note the different CL response of groundmass carbonates (gm) in the kimberlite matrix, rare dark "plates" and yellow-orange coarser (sparry) calcite in the "detached diapir". c) A second generation of calcite $\left(\mathrm{cal}_{2}\right)$ replacing an earlier, concentrically zoned, calcite $\left(\mathrm{cal}_{1}\right)$ in the Premier kimberlites.

Electron microprobe analyses reveal that early-crystallising carbonates are typically $\mathrm{Sr}$-rich calcite (0.6$2.1 \mathrm{wt} \% \mathrm{SrO}$ ), sometimes coupled with slight enrichment in $\mathrm{Ba}, \mathrm{Mg}, \mathrm{Fe}$ and $\mathrm{Na}(<0.2$ wt.\% oxides). Although this $\mathrm{Sr}$ enrichment is a characteristic feature in all the studied kimberlites, minor compositional variations can be correlated with different kimberlite fields. For example, very high $\mathrm{Sr}$ contents are found in the groundmass carbonates of the Lac de Gras kimberlites, constrasting with the lower values typical of the South African kimberlites. The composition of the secondary carbonates clearly differs from that of the early carbonates ( $\mathrm{Sr}$ contents are either negligible or very high (> $3 \mathrm{wt} \%$ $\mathrm{SrO})$ ) and varies significantly between kimberlites. Although dolomite commonly has significant amounts of $\mathrm{Mn}$ and $\mathrm{Fe}(0.20-0.85 \mathrm{wt} \% \mathrm{MnO}$ and up to $2.6 \mathrm{wt} \% \mathrm{FeO})$, the values for Sr, Ba, REE and $\mathrm{Na}$ are usually lower than that in the groundmass.

\section{$O$ isotope analysis in kimberlitic carbonates}

Different carbonate generations have clearly distinct $\delta^{18} \mathrm{O}$ composition. As shown in Fig. 2a, primary carbonates typically show values within the mantle range $\left(\delta^{18} \mathrm{O}=6-9 \%\right)$, whereas secondary carbonates commonly have higher values $\left(\delta^{18} \mathrm{O}=12-23 \%\right.$ o). A remarkable exception was found in the $\sim 1200 \mathrm{Ma}$ Premier kimberlite, where texturally secondary calcite yields an oxygen isotope signature typical of mantle-derived carbonates $\left(\delta^{18} \mathrm{O}=7-9 \%\right)$. Moreover, our results demonstrate that bulk-carbonate $\delta^{18} \mathrm{O}$ data commonly differ from the values obtained from in situ analyses (Fig. 2a).
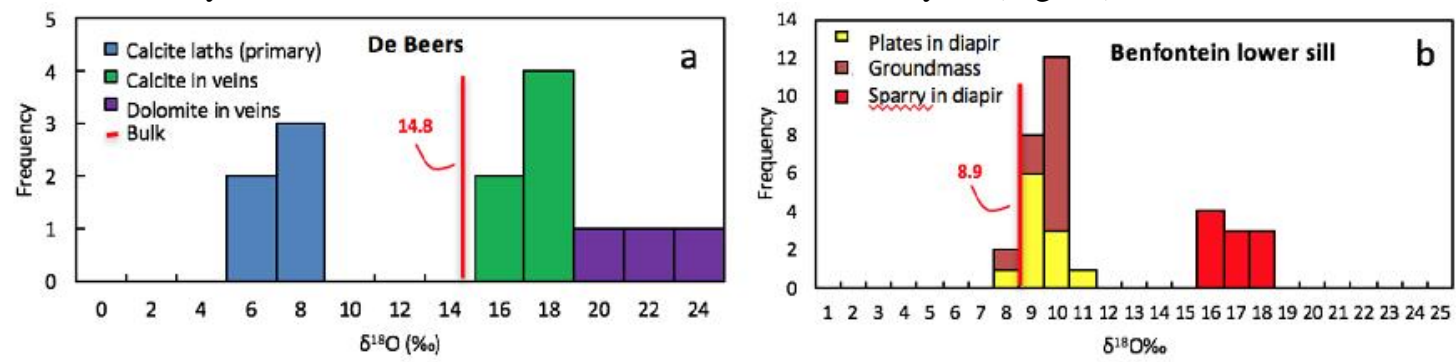

Figure 2: $\delta^{18} \mathrm{O}$ histograms for carbonate grains in the De Beers kimberlite and Benfontein lower sill. The $\delta^{18} \mathrm{O}$ values of primary and secondary carbonates differs from the bulk carbonate analyses.

In situ analyses also revealed an unexpected complexity in the processes that led to the formation of magmatic carbonates and "diapirs" in the lower sill of the Benfontein sill complex (Fig. 2b). The groundmass carbonate in this sill shows a characteristic and homogeneous mantle-like signature $\left(\delta^{18} \mathrm{O}=8.3 \pm 0.6 \%\right.$ ) , which overlaps with the isotopic composition of the Sr-rich calcite plates (Fig. 1b) 
found in the "diapirs" $\left(\delta^{18} \mathrm{O}=7-9 \%\right.$ ). However, the sparry calcite accounting for the bulk of the carbonate diapirs has significantly heavier $\mathrm{O}$ isotope values $\left(\delta^{18} \mathrm{O}=14.5-16.5 \%\right.$ ), which would explain the wide range of values $\left(\delta^{18} \mathrm{O}=8.73\right.$ and $14.34 \%$ ) previously reported by Dawson and Hawthorne (1973). Secondary dolomite in veins has higher O isotope values than the calcite crystallising in the same vein (e.g. $\delta^{18} \mathrm{O}=20-23 \%$ o vs $\delta^{18} \mathrm{O}=16-18 \%$ o).

\section{Discussion and conclusions}

Carbonate petrogenesis in kimberlites is complex and can only be understood by integrating detailed textural characterisation and in situ geochemical measurements. The composition of primary carbonates (groundmass, laths, magmatic segregations and in sills) is strikingly homogeneous in all kimberlites worldwide (calcite with 0.6-2.1 wt \% SrO), although minor variations occur between different kimberlite fields. However, the composition of secondary carbonates (replacing early groundmass phases, as segregations or as crosscutting veins) clearly varies between different localities. This is consistent with crystallisation from late fluids strongly influenced by local conditions, including wall rock composition, temperature and/or latitude. In situ isotopic analysis have shown that primary kimberlitic carbonates commonly preserve their mantle signature $\left(\delta^{18} \mathrm{O}=6-9 \%\right)$, whereas secondary carbonates commonly have heavier $\delta^{18} \mathrm{O}$ values. The mantle-like values $\left(\delta^{18} \mathrm{O}=7-9 \%\right.$ of oxturally secondary carbonates in the Premier kimberlite could be related to deuteric (i.e. late-stage magmatic) kimberlitic fluids. Alternatively, such isotopic signature may have been imprinted later by melt-related fluids of a large gabbro intrusion (Bartlett 1994).

The significant $\delta^{18} \mathrm{O}$ difference between primary carbonates and bulk kimberlite rocks undoubtedly shows that bulk compositions are not representative of the composition of the parental kimberlitic melt, even for the least altered kimberlites. Therefore this work highlights the necessity of in situ characterisation of each carbonate type in order to identify its origin and ultimately define the isotopic composition of magmatic carbonates. This study provides a robust foundation for our ongoing project, which will combine the present $\mathrm{O}$ isotope data with additional in situ $\mathrm{C}$-and $\mathrm{Sr}$-isotope analysis to better constrain the composition and volatile concentrations of kimberlitic melts.

\section{References}

Armstrong JP, Wilson M, Barnett RL, et al (2004) Mineralogy of primary carbonate-bearing hypabyssal kimberlite, Lac de Gras, Slave Province, Northwest Territories, Canada. Lithos 76:415-433. doi: 10.1016/j.lithos.2004.03.025

Bartlett PJ (1994) Geology of the Premier diamond pipe. In: XVth CMMI Congress. Johannesburg, pp 201-213

Dawson JB, Hawthorne JB (1973) Magmatic sedimentation and carbonatitic differentiation in kimberlite sills at Benfontein, South Africa. J Geol Soc London 12:61-85.

Giuliani A, Phillips D, Kamenetsky VS, et al (2014) Stable isotope (C, O, S) compositions of volatilerich minerals in kimberlites: A review. Chem Geol 374-375:61-83. doi: 10.1016/j.chemgeo.2014.03.003

Kamenetsky VS, Kamenetsky MB, Sharygin V V., et al (2007) Chloride and carbonate immiscible liquids at the closure of the kimberlite magma evolution (Udachnaya-East kimberlite, Siberia). Chem Geol 237:384-400. doi: 10.1016/j.chemgeo.2006.07.010

Kopylova MG, Matveev S, Raudsepp M (2007) Searching for parental kimberlite melt. Geochim Cosmochim Acta 71:3616-3629. doi: 10.1016/j.gca.2007.05.009

Mitchell RH (1994) Accessory rare earth, strontium, barium and zirconium minerals in the Benfontein and Wesselton calcite kimberlites, South Africa. In: Meyer HOA, Leonardos OH (eds) Kimberlites, related rocks and mantle xenoliths. 5th International Kimberlite Conference. CPRM Special Publication, Araxa, Brazil, pp 115-128

Skinner EMW, Clement CR (1979) Mineralogical classification of southern African kimberlites. In: Boyd FR, Meyer HOA (eds) The Mantle Sample. 2nd International Kimberlte Conference. American Geophysical Union, Washington, D. C., pp 129-139 